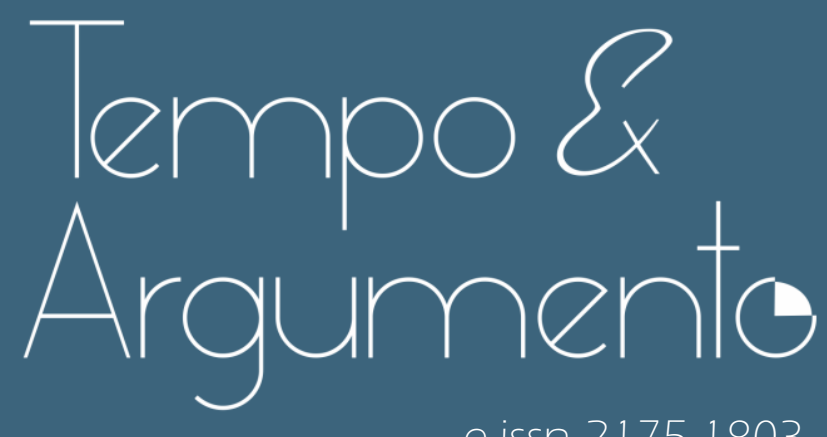

e-issn 2175-1803

\title{
Subvertendo a ordem: resistência operária entre os têxteis na década de 1950
}

- Jormana Maria Pereira Araújo

Doutora em História pela Universidade Federal do Ceará (UFC).

Professora da Secretaria da Educação do Estado do Ceará.

Fortaleza, CE - BRASIL

lattes.cnpq.br/1423751116382323

jormana_araujo@yahoo.com.br

(D) orcid.org/0000-0002-0600-7233

Para citar este artigo:

ARAÚJO, Jormana Maria Pereira. Subvertendo a ordem: resistência operária entre os têxteis na década de 1950. Tempo e Argumento, Florianópolis, v. 12, n. 30, e0102, maio/ago. 2020.

dot http://dx.doi.org/10.5965/2175180312302020e0102

Recebido: 30/09/2019

Aprovado: 03/06/2020 


\title{
Subvertendo a ordem: resistência operária entre os têxteis na década de 1950
}

\author{
Resumo \\ Este artigo analisa as lutas do operariado têxtil cearense, especialmente da \\ Fábrica Santa Cecília, num período de recrudescimento da disciplina e ritmos de \\ trabalho, durante os anos de 1950. Para isso me amparo na História Social do \\ Trabalho, problematizando a escrita subversiva inscrita no jornal comunista $O$ \\ Democrata, em que defendo que o operariado têxtil buscou construir um projeto \\ alternativo de industrialização no Ceará, que levasse em conta a dignidade do \\ trabalhador, expressa em direitos sociais e do trabalho. Em meio à infrapolítica \\ dos grupos subordinados, a classe trabalhadora enfrentou as pressões do \\ mercado e patrões, de forma quase sempre oculta, e por vezes, de modo público \\ e brutal.
}

Palavras-chave: Artes da Resistência e Sociedade. Indústria Têxtil. Direitos e Lutas Sociais. Trabalhadores - Ceará.

\section{Subverting the order: worker resistance among textiles in the 1950s}

\begin{abstract}
This article analyzes the struggles of Ceará's textile workers, especially the Santa Cecilia Factory, in a period of increased discipline and work rhythms, during the 1950s. For this, it relies on the Social History of Work, problematizing the subversive writing registered in the communist newspaper O Democrata, in which I defend that the textile workers sought to build an alternative industrialization project in Ceará, which took into account the dignity of the worker, expressed in social and labor rights. In the midst of the infrapolitics of subordinate groups, the working class faced pressures from the market and employers, in a way that was almost always hidden, and sometimes, in a public and brutal way.
\end{abstract}

Keywords: Arts of Resistance and Society. Textile Industry. Social Rights and Struggles. Workers - Ceará. 


\section{Introdução}

A história aqui inscrita trata do operariado que trabalhou nas terras cearenses durante a década de 1950, proveniente da Paraíba, dos inúmeros municípios do interior cearense, e da própria capital - longas gerações de homens, mulheres e crianças que foram se instalando na periferia da cidade de Fortaleza, quando em busca de melhores condições de vida, fugiam em levas para cá, para o norte e o centro-sul do país, como bem conhecemos dos causos contados entre as famílias, e da historiografia sobre o tema (CÂNDIDO, 2014; CARDOSO, 2011; FONTES, 2008; NEVES, 2000).

Entre as narrativas, algo chocante: um trabalhador mata o patrão dentro da Fábrica! Tamanha reviravolta! Logo pensei na minha tese de doutorado (ARAÚJO, 2018). E então vieram as dificuldades: o acesso à documentação do Arquivo Público do Estado do Ceará, incluindo o arquivo intermediário, levou-me a certa decepção, pois nada de processo-crime à vista. O mesmo acontecia aos processos trabalhistas do operário que também não se encontravam no Arquivo do Tribunal Regional do Trabalho. Passei então aos jornais da Biblioteca Pública Menezes Pimentel, e logo a decepção se converteu em entusiasmo, à medida que digitalizava matérias várias, referentes ao crime nos periódicos locais.

Nesse mesmo acervo também me deparei com um jornal comunista valiosíssimo para o estudo dos trabalhadores no Ceará, voltando-me a digitalização das reportagens sobre os trabalhadores têxteis, cujos exemplares são os de 1950-1-2-3-4-7-8. A incompletude nos exemplares, como deve ter percebido o leitor, em grande parte se deve a negligência dos poderes públicos quanto a sua conservação, podendo sobrar quase nada em muito pouco tempo'. Através dele, d'O Democrata, comecei a traçar uma linha explicativa sobre a resistência operária aos ditames do recém-chegado italiano Dante Bonorandi (patrão assassinado) na Fábrica Santa Cecília, um empreendimento do Cotonifício Leite Barbosa, no Ceará. 
Segundo Zenilde Baima Amora (1994), as indústrias têxteis estão entre os primeiros empreendimentos industriais no país, e aqui no Ceará, a Fábrica de Tecidos Progresso é pioneira, surgindo em 1884, num contexto de crise internacional do algodão, provocando a baixa do preço do produto, além dos altos custos de transporte e embalagem. Em seguida vieram a Siqueira Gurgel, a Philomeno S/A, a Fábrica Santa Cecília, assim como outras pequenas unidades fabris.

A indústria têxtil surge aqui e em outras capitais nordestinas como parte do processo de aproveitamento da produção agrícola regional, acontecendo o mesmo aos curtumes e à indústria de óleos vegetais, atribuindo um caráter urbano à cidade-capital Fortaleza, uma coletora e transformadora dos produtos advindos do interior do Estado, em especial, de Quixeramobim, Quixadá e Mombaça - alguns dos municípios que compunham a zona algodoeira local. No que trata a década de 1950, nomeada por Elizabeth Fiúza Aragão (1989, p. 81) como "período de involução da indústria têxtil cearense", algumas mudanças foram sentidas no que trata às especialidades da produção, iniciando o Cotonifício Leite Barbosa ${ }^{2}$ na lida com tinturarias, acabamento, alvejamento e estamparia, passando a lançar no mercado tecidos finos para camisas. Foi tempo também de entrada dos produtos sintéticos.

Bonorandi - acionista, diretor industrial, engenheiro, superintendente; sim, ele foi de tudo isso um pouco, vai focar sua ação na fábrica Santa Cecília, em expansão. Ocupando uma função bastante singular no negócio que acabava de investir, era um homem da área, estando sempre a percorrer as diversas secções da fábrica, acompanhando de perto o modo como estava procedendo a produção. Aqui se iniciava o contato com os trabalhadores.

Acontecia também naquele momento, uma percepção bastante singular do outro. Patrão (italiano) e operariado (entre os quais, nordestinos, mestiços e pobres) não se entendiam, especialmente quando uma série de mudanças

\footnotetext{
2 Nome dado a uma rede de indústrias têxteis no Ceará, entre as quais estão a Fábrica Santa Cecília (Fortaleza) e Fábrica Santa Teresa (Aracati). Nos anos de 1970 seriam criadas mais duas outras fábricas, Fábrica Santa Lúcia e Fábrica Santa Inês, ambas instaladas na capital cearense, todas pertencentes a família Leite Barbosa/Pinheiro. A Fábrica Santa Cecília, mais especificamente, trata-se de uma empresa do tipo familiar, que no ano de 1954, segundo o Almanaque do Ceará, era a maior produtora de tecidos do Estado, somando 10.512.486 metros.
} 
passou a ser efetuada nas relações de trabalho, que de modo bastante arbitrária, dava a entender que imperava naquele espaço a Lei do Patrão.

Contudo, das ameaças, denúncias e adjetivos, surgia o sentimento comum de indignação vivido pelos trabalhadores, que no seu conjunto, possibilitou um largo diálogo com os estudos do antropólogo norte-americano James Scott (2013), apresentando-nos a seguinte ideia: existe entre os sujeitos uma avaliação constante da dominação, surgindo daí, discursos ocultos e discursos públicos, perfazendo uma infrapolítica dos grupos subordinados. A essa forma de ação política dos sujeitos, o autor nomeia por resistência, uma arte utilizada pelos grupos subalternos. Dialogando ainda com essa concepção, os apontamentos de Michel de Certeau (1994) também ganharão destaque à medida que forem analisadas as linguagens dos sujeitos expressas nos jornais, a questão do uso e das inversões discretas como elementos avaliativos do que estava acontecendo nas relações entre patrão e trabalhadores.

Para o artigo em curso, analiso que o jornal O Democrata teve função decisiva no processo de compartilhamento das angústias e indignações sentidas pelo operariado da FSC, auxiliando-o no processo de fazer-se classe, cujo entendimento do trabalho industrial não se dava nos marcos do que estava sendo imposto, momento esse em que a disciplina e o ritmo de trabalho são intensificados na fábrica, num processo de interiorização do taylorismo.

\section{Uma escrita de denúncia: Bonorandi, você não escapa!}

O encontro com Dante Bonorandi aconteceu no momento em que tomei nota do seu assassinato. Posteriormente, lendo o jornal O Democrata, percebi que várias eram as notícias envolvendo seu nome, sempre em tom de denúncia, mal referindo-se a Audízio Pinheiro, presidente e sócio majoritário do Cotonifício Leite Barbosa. Surgia, desde então, a intenção de seguir seus passos, e compreender como o italiano conduzia as relações de trabalho, e assim perceber as ações operárias em tempos os quais pairavam a linguagem dos direitos.

Talvez seja difícil imaginar o exorbitante grau de exploração que os empresários da indústria têxtil realizaram nestas terras do Ceará, e eles o fizeram recorrendo ao discurso da necessidade de implementar a civilização e o 
progresso. Para isso, buscaram intensificar o uso dos mais recentes métodos de produção industrial da época, como estava acontecendo em várias partes do mundo.

As leis trabalhistas, ou mesmo a fiscalização a ser realizada pelos órgãos estatais nas fábricas, pareciam estar longe de dar conta das arbitrariedades ali existentes, indo de encontro à determinação do ministro do trabalho João Goulart, para quem o bem-estar do operário era imprescindível nos marcos de uma democracia que obrigava patrões e empregados a cumprirem a lei (FERREIRA, 2005, p.122).

À primeira vista, os casos que veremos a seguir podem nos levar a crer que se tratavam de situações isoladas, ou que o editor (comunista) do jornal estava procurando criar algum fato político para forjar indignação nas massas; mas não era isso o que acontecia. Ao longo de algumas décadas de experiência radicalizada do movimento operário no Ceará, encontra-se uma série de sujeitos perseguidos, presos e adoecidos, vê-se um passado marcado por arbitrariedades corriqueiras e de todos os tipos, passíveis de ser captadas, em grande medida, através daquele jornal.

Geraldo da Silva Nobre (2006, p. 149) aponta que O Democrata começou a circular no Estado do Ceará no dia 05 de agosto de 1945, tornando-se, posteriormente, porta-voz dos comunistas locais. Segundo Ildefonso Rodrigues Lima Neto (2006, p. 16-17), o jornal inicialmente pertenceu ao advogado Olavo Oliveira, que o teria vendido por 250 Contos de Réis aos comunistas, e desde então, passaram a contar com uma rede de apoiadores a dar suporte material ao vespertino. São corriqueiras as doações de chumbo para a produção do jornal, especialmente pelos trabalhadores gráficos.

Na Rua Floriano Peixoto, 814, no bairro Centro, em Fortaleza, era instalada em 1947 a sede do jornal. E surgia em momento de abertura política, após o fim da ditadura Varguista e término do período de intervenção do governador Menezes Pimentel. O periódico entrava em cena disputando espaço com outros seis jornais submetidos ao crivo do mais recente governador, Faustino de Albuquerque. Contudo, ao contrário dos demais, O Democrata teve desde o 
primeiro exemplar ao último, uma característica primorosa aos pesquisadores que almejam escrever sobre os pobres, a escrita subversiva:

Conforme a leitura minuciosa dos periódicos, percebe-se a relação dos jornais [O Democrata] com os trabalhadores de maneira acentuada, controversa, plena de intersecções, repleta de pistas para possível entendimento dos conflitos no mundo do trabalho. As páginas impressas, carregadas de ideais, em busca de mudanças nas condições de vida, trabalho, mudanças políticas e de direitos, tinham como fonte de inspiração as publicações de autores iluministas, socialistas, anarquistas e marxistas. As palavras de contestação percorriam os territórios da divergência e faziam o contraponto com as ideias conservadoras e de manutenção da ordem (LIMA NETO, 2006, p. 26).

Com o modo subversivo de ser é que o jornal O Democrata nos interessa, cuja característica se antagoniza bastante com os outros periódicos que circulavam na cidade naqueles tempos de tendência mais ou menos conservadora. Isso se justifica em razão desses últimos se referirem aos trabalhadores, quase sempre nos momentos de forte embate de classes (greves, por exemplo), e em proporções distintas, deslegitimando o movimento por eles organizado.

Já com O Democrata tive a possibilidade de entender que a Fábrica Santa Cecília, instalada no distrito da Parangaba, não é uma coisa dada, em que o algodão naturalmente parava ali, entrava numa máquina e saía tecido pronto, tingido e acabado, para todos, indistintamente, fazerem uso. Na versão do jornal, um processo de produção como o que acontece numa fábrica, move muitas pessoas e interesses, expressando-se numa série de conflitos, noticiados por ele, cotidianamente.

Aqui não é o caso, contudo, de isentá-lo de suas pretensões políticas, e afinal, qual jornal não as têm? Analisando o vespertino cearense, Ildefonso Lima Neto (2006) procura ainda recuperar sua trajetória destacando que entre os militantes da esquerda, O Democrata possuía função estratégica para o Partido Comunista Brasileiro (PCB): era um aparelho da contravenção a nível local, cujo objetivo era propagar outras ideias, ganhando simpatizantes para a causa. Mas 
vale destacar que por todo o Brasil foram construídas letras com esse mesmo propósito, recebendo títulos variados ${ }^{3}$.

Desse modo, se por um lado as formas políticas de organização dos trabalhadores quase sempre fizeram conexões com a imprensa, por outro, as publicações ali realizadas almejavam ser mais do que ser porta-voz dos oprimidos, eram instrumentos de luta no processo do fazer-se classe.

Os trabalhadores das mais diversas categorias logo perceberiam essa característica, almejando que suas reivindicações fossem parar no jornal. Entre eles, estivadores, gráficos, ferroviários, operários da construção civil, da indústria de óleos vegetais, têxteis e vários outros. O mesmo acontecia ao operariado da Santa Cecília. Com repórter quase sempre à espreita nas proximidades do portão da fábrica, não faltavam palavras ressentidas sobre longas e intensas jornadas, as confusas remunerações, os salários de fome, as perseguições diversas, etc. Por vezes, a procura pelo repórter acontecia na própria redação, quando se juntavam colegas em grupos, indignados, vindo relatar algum conflito que os afligia. E foi assim que em 09 de outubro de 1951, o nome de Dante Bonorandi ${ }^{4}$ aparece pela primeira vez no jornal:

Sr. Redator,

Desejamos denunciar nesta carta as atividades do indivíduo Vicente, mais conhecido pelo apelido Cavalinho de Ola. Esse indivíduo já foi enxotado da Fábrica "São José" porque os operários não podiam tolerar seus atos, e agora se instalou aqui e vem cometendo as piores cousas na secção de acabamento. Sua especialidade é roubar nossos salários, diminuindo a produção para agradar aos patrões. Procura todos os meios possíveis para avançar nos nossos salários e quando reclamamos, ele vai ao escritório e acusa os contramestres, ao mesmo tempo que insulta

\footnotetext{
${ }^{3}$ Além d'O Democrata, que circulava no Ceará, eis alguns títulos de jornais comunistas (do PCB) que circularam pelo país: A Classe Operária (Rio de Janeiro, 1946-1947), Estado de Goiás (Goiânia, 1946-1947), Folha Capixaba (Vitória, 1946-1947), Folha do Povo (Recife, 1945-1947), Folha Popular (Natal, 1946-1947), Hoje (São Paulo, 1945-1947), Jornal do Povo (João Pessoa, 19451947), Jornal do Povo (Aracaju, 1946-1947), Luta (Manaus, 1946), O Momento (Salvador, 19451947), Seiva (Salvador, 1947), Tribuna do Povo (São Luís, 1946-1947), Tribuna do Povo (Uberlândia, 1946-1947), Voz do Trabalhador (Porto Alegre, 1945). Informação extraída do site:

https://pcb.org.br/fdr/index.php?option=com_content\&view=article\&id=202:os-jornaiscomunistas-e-seus-responsaveis\&catid=1:historia-do-pcb acesso: 09/04/2018.

${ }^{4}$ É em 1951 que o nome de Dante Bonorandi também aparece pela primeira vez nas atas de assembleia do Cotonifício Leite Barbosa. Em virtude do falecimento do 1o. Diretor Industrial, Newton Camocim Leite Barbosa, ele é escolhido pelos acionistas para preencher a vaga. (ASSEMBLEIA..., 1951).
} 
os operários. A fim de que ninguém dê conta dos roubos, o tal Cavalinho proíbe a passagem de operários de outras secções pela secção de acabamento e, quando batem às dez horas, fecha o portão para poder agir à vontade.

Esse indivíduo tem um parceiro da mesma marca. Trata-se do fiscal-geral, que também já saiu da "São José" às carreiras. Além de ajudar nos roubos, trata as operárias com brutalidade. Outro dia, suspendeu uma moça porque ela, não tendo o que fazer, por falta de material, se achava sentada. Na semana passada outra foi suspensa por esse fiscal pelo fato de se haver recusado a trabalhar à noite. A operária - uma menina ainda, alegou que morava longe e não podia ir para casa sozinha, alta hora da noite, mas nem assim escapou à fúria do perseguidor.

Para mostrar até que ponto chega o atrevimento e a falta de respeito deste fiscal, basta dizer que um dia desses ele chegou na porta de uma privada e deu ordem para arrastar pelos cabelos uma operária que lá se encontrava. O nome desse degenerado é Sallas.

O chefe e protetor desses verdadeiros bandidos que agem aqui na fábrica é o gerente nazista Bonorandi. Ele próprio faz a maior confusão na secção de acabamento com o fim de roubar a produção. Até as antigas papeletas, em que vinha anotada a produção, foram abolidas para que ninguém saiba quanto ganhou na semana. A fábrica paga o que quer pagar.

Assim são as cousas aqui na "Santa Cecília". Além de roubadas somos constantemente insultadas pelos aduladores dos patrões. Mas, Sr. redator, nós estamos dispostas a dar uma lição a esses canalhas. E ainda sairá notícia dessa lição. Operárias da "Santa Cecília" (VERDADEIROS..., 1951, n.1957, sem paginação).

A carta assinada pelas operárias denota a possibilidade de apreciação de um discurso (até então) oculto. O questionamento das operárias não se centra nos baixos salários e longa jornada, ainda que eles estejam presentes e incomodem, mas nas constantes humilhações: puxões de cabelo, impossibilidade de dizer não faço, não posso; suspensão indiscriminada, contabilização arbitrária da produção. Tudo isto as coloca numa situação-limite acumulada, reverberando-se na carta.

Vale destacar que sua escrita também revela a indignação por tantas vezes engolida na frente dos chefes, aparentando aceitação, subordinação e acato às decisões arbitrariamente tomadas. Fora da fábrica e longe da vigilância de seus superiores, o discurso oculto era certamente partilhado e discutido entre aquelas que se viam como iguais, alimentando uma cultura dissidente. Entendiam, antes de tudo, que tinham de sobreviver, pagar as contas e, para isso, continuar empregadas. Por isso o anonimato naquela denúncia pública era imperativo. 
Também chama atenção o modo como vem à cena adjetivos criados entre o operariado para referir-se aos poderosos e aqueles que um dia devem ter saído do seu próprio meio, mas agora representavam os anseios dos patrões: lacaios, bandidos, Cavalinho de Ola, perseguidores, degenerados, aduladores, canalhas, fascista, nazista. O que é possível de ser apreciado é a reverberação pública do que elas pensavam a respeito das práticas cometidas pelos chefes, jamais professadas no cotidiano de trabalho, quando parecia que as coisas iam bem.

Percebe-se também o quão viva estava a memória da experiência autoritária na Europa, e como estavam mudando as maneiras de ver o mundo, entendendo práticas fascistas/nazistas como equivocadas, típicas de um regime fechado e sem diálogo. Tem-se dúvidas, todavia, se os termos surgem de uma escrita conjunta, entre operárias e editor ou se elas eram leitoras assíduas do jornal e assimilaram expressões que já eram utilizadas contra supervisores daquela e de outras fábricas, escrevendo sozinhas a carta. O que parecia certeza era a analogia entre a nacionalidade italiana de Bonorandi e a memória dos horrores em seu país. Percebe-se, porém, uma constante presença desses termos associados ao diretor industrial ao longo das edições d'o Democrata, assim como às chefias malquistas noutras fábricas. E choca.

Partindo das elaborações teóricas do intelectual Michel de Certeau (1994, p. 94-5) e para que se reflita sobre esse jogo de linguagem do operariado, pegase de empréstimo o que ele nomeou por uso, e interpreta-se aqui desta forma: a partir das ações dos supervisores da Fábrica Santa Cecília (produtores da língua), o operariado fabricaria seu murmúrio incansável (uso, ou inversões discretas) provocado pelo consumo da linguagem dos poderosos. Se a prática da linguagem funda a opressão, o operariado se utilizaria de seus elementos para construir o discurso da resistência, atribuindo-lhe potência.

A produção da linguagem do trabalho (pretensamente livre) pelos empresários e Estado, torna-se objeto de manipulação pelos consumidores, que constroem armadilhas no seu processo de assimilação: dão a entender que incorporam a dominação, tal qual, sem o terem feito. Ainda que não sejam sempre articuladas tais manipulações, compondo um discurso oculto/público, elas acontecem e apontam para uma percepção outra: ser operariado não 
significava acatar maus tratos, ter corpo e tempo controlados, ou ver-se subjugados à rotineira intromissão.

Essa carta publicada n'O Democrata é um modelo de fonte que vem sendo analisado nos estudos em torno da história da escrita e da leitura no mundo do trabalho. Após observação de realidades sociais distintas e em diferentes países, inclusive o Brasil, Adelaide Gonçalves conclui que o analfabetismo não fora elemento a tornar impraticáveis as ideias subversivas. A palavra impressa ou o veículo oral, ainda segundo Adelaide Gonçalves (2003, p. 60-62), foram "resultado[s] [do] esforço de inteligibilidade do mundo e da busca de eficácia em disseminar conteúdos diretamente vinculados a seu propósito pedagógico, organizativo e doutrinário”. Diz a autora que se lia à noite, após um dia de intensa labuta; no trabalho, driblando a fiscalização dos patrões, gerentes e contramestres; mas lia-se. Para o caso em questão, a busca pelo jornal comunista pode denotar um exercício na composição da cultura letrada.

Se fosse possível imaginar o que diria Dante Bonorandi acerca do que escreviam a seu respeito, desse tempo de descanso usado pelo operariado do Cotonifício para the falarem mal, adjetivando-o pejorativamente, com certeza diria que aquilo era uma perda de tempo útil combinada com impertinência. Eram nesses momentos de impertinência que foram constituídos os registros do que pensava o operariado sobre o modo como aconteciam as relações de trabalho, a natureza do ofício realizado, os diálogos e conflitos que não se encerravam entre as paredes da fábrica. Nesse processo de comunicação, é válido destacar ainda que por mais que fossem evitadas trocas de ideias dentro da fábrica, onde as secções eram isoladas uma das outras a fim de que não se falasse da produtividade, o operariado conversava, sabendo até mesmo do que estava acontecendo noutras fábricas.

Bonorandi, Sallas e Vicente são nomes recorrentes entre as reclamações que aparecem n ' O Democrata. Os dois primeiros são italianos, o segundo, ao que parece, é brasileiro. Vale observar que, dos três, somente Bonorandi era acionista da fábrica, aparecendo aqui também com função de mando na produção, sempre a alterar para pior as condições de trabalho: 
A secção de acabamento, segundo também o depoimento dessas trabalhadoras, é a cena do crime que o italiano fascista Bonorandi e seus agentes praticam todos os dias. Os operários foram até proibidos de passar por aquela secção, justamente para que não vejam a escamoteação que ali é feita. Tudo que poderia servir para indicar a produção dos operários em cada semana foi abolido, inclusive as papeletas que há longos anos eram usadas. No curso desta semana desapareceu toda a produção de uma operária da secção de tecelagem provocando enérgicos protestos da prejudicada.

Outra operária novata que os patrões supunham houvesse protestado também, foi demitida pelo gerente Bonorandi, em virtude de denúncia do capacho Vicente. Essa operária vinha sendo marcada desde que começara a trabalhar na fábrica, pelo fato de repelir certas propostas indecorosas feitas pelo dito "Cavalo de Ola" (UM VERDADEIRO..., 1951, n. 1467, sem paginação).

É característica das fábricas têxteis a presença feminina na produção, especialmente como operárias da fiação. Isso acontece desde o início da industrialização, envolvendo uma relação de gênero bastante complexa: permissão dos pais/maridos para trabalhar; iniciação da vida de trabalho muito cedo, dado o imperativo da necessidade; concessão para trabalhar apenas se a secção fosse composta por mulheres, sobrepondo-se ali os preceitos morais, etc (MOURA, 1982; PENA, 1981; RODRIGUES, 1979).

Entre o ser mulher, imposto socialmente pelas relações sociais, e o tornarse mulher, reinventando o gênero, há uma vivência baseada na expectativa de ver os direitos sendo iguais entre mulheres e homens, especialmente quando se trata de ter salário justo através da presença da papeleta para medir a produção e da dignidade auferida (nada de gritos, puxões de cabelo, ou assédio sexual). Em seus modos de vida, elas elaboraram, assim como os demais operários, um projeto, uma expectativa de indústria onde não houvesse espaço para abusos.

Na sua constante ronda na produção, Dante Bonorandi aproximava-se cada vez mais da supervisão do operariado, o que deveria agradar bastante os demais acionistas, vendo-se representados com a imagem da dominação patronal. O engenheiro que trazia consigo conhecimentos da mais recente ordem de funcionamento industrial, especialmente de aspectos relativos a tempo, disciplina e trabalho, procurava reorganizar a produção na Fábrica Santa Cecília, gerando muitos descontentamentos, como pode ser visto da percepção de mudança: 
Acerca das condições de trabalho, disseram que um número elevado de trabalhadores vem trabalhando até dez horas da noite, todos os dias, por imposição do gerente. Esses trabalhadores homens e mulheres - têm apenas uma hora de descanso nessa jornada longa que começa às 6 da manhã e vai até às 10. Uma hora para o almoço. Na secção de tecelagem trabalha-se com três máquinas, o que significa um esforço duplicado que afinal, só serve mesmo aos patrões. O aumento da produtividade individual, com o trabalho em três máquinas, é pequeno e pouco aumenta os salários. Entretanto, juntando esse pequeno aumento de cada operário, têm os patrões um acréscimo considerável na produção geral, o que determina maiores lucros. [...] Embora o trabalho de 6 da manhã às 10 da noite não seja imposto, os operários aceitam porque é uma maneira de melhorar os salários miseráveis que recebem. O que ganham em oito horas de trabalho não chega sequer, para comprar um quilo de feijão. Têm, portanto, de enfrentar uma jornada de 15 horas para não morrer de fome; entretanto, a verdade é que se arriscam a morrer vitimados pela tuberculose (UM VERDADEIRO, 1951, sem paginação).

Mais uma vez a denúncia é feita pelas operárias que trabalhavam na secção de acabamento, atribuindo a Dante Bonorandi tudo aquilo que parece desarranjo na produção. Contudo, o que se apresenta como problema para elas, é solução para o engenheiro industrial, pois estava em curso a interiorização do taylorismo aliada a construção do laboratório secreto da produção. Conceituada por José Sérgio Leite Lopes (1988, p. 301), essa expressão é elaborada a partir da sua análise sobre as relações de trabalho na Companhia de Tecidos Paulista, em Pernambuco, no período que perpassa o recorte temporal aqui em apreço. Segundo o autor, uma das particularidades da indústria têxtil, ali e noutras partes do país, é a prática do pagamento do salário por produção, e que isso sempre deu margem aos industriais de suscitarem controvérsia em relação às deliberações do Ministério do Trabalho quanto ao assunto, possibilitando-lhes também controlar e manipular a operação no momento de transformar o salário mínimo calculado por tempo, em salário mínimo calculado por produção.

E era isso o que incomodava o operariado, gerando vários embates com seus patrões em âmbito local e nacional. Na Fábrica Santa Cecília, a situação era pior, pois foi abolida a papeleta de produção, atuando um laboratório mais secreto ainda, cujo entendimento era de que não cabia ao operariado deter os valores da produção, e sim a administração fabril. Arbitrariamente, era decidido pela cúpula quanto deveria receber cada operário, e isso gerava ainda mais 
desconfianças. Por outro lado, se some a papeleta, some o que ficou registrado de trabalho, o que invalidaria a reivindicação da operária, caso ela fosse fazer denúncia interna, na fábrica, ou externa, nos órgãos de fiscalização do trabalho. E além disso, reclamar dos cálculos do laboratório secreto passou a ser visto como ato de indisciplina, ao tempo que legitimava demissões, como aconteceu na seç̧ão de tecelagem.

Esses inerentes conflitos que se acumulavam na Fábrica tornavam-se, portanto, ingredientes perfeitos para a circulação das ideias democráticas propagadas pelos comunistas, que tiveram uma forte atuação no movimento sindical.

\section{Movimento Sindical}

Apontando como saída desse estado de exploração e miséria, a luta a ser realizada pelo operariado, o jornal O Democrata também defende que a mediação devia ocorrer sempre pela via sindical - entendendo-a como importante instrumento de luta dos trabalhadores, mas que naqueles tempos contava com um viés democrático, balizado e herdeiro do Estado Varguista, cuja proposta corporativa e intermediária era manter as hierarquias visando diminuir as desigualdades sociais:

Nosso modelo sindical foi, assim, construído visando ao controle social que pudesse levar à construção de um país harmonioso e pacífico. Visava impor uma filosofia social em contraposição à filosofia individualista do liberalismo ou à filosofia classista do socialismo. Tinha também como meta criar atrativos para os trabalhadores saírem do campo e se dirigirem ao trabalho industrial nas cidades. (...) A legislação sindical, ao criar alguns direitos apenas para os trabalhadores urbanos, introduzia uma maneira de tornar o trabalho industrial mais atrativo. Além disso, e talvez o mais importante, através dos sindicatos, o governo tinha instrumentos poderosos para controlar as atividades desses trabalhadores, evitar greves e até mesmo silenciar o movimento operário. Ou seja, com uma das mãos o governo reconhecia os sindicatos como instrumentos de organização, uma velha demanda dos trabalhadores em todo o mundo, e com a outra, criava restrições para que esses sindicatos pudessem ser usados pelos trabalhadores como instrumentos de reivindicação e de mobilização (D 'ARAÚJO, 2003, p. 220). 
Ainda que se sobrepusesse a instância classista de análise, caracterização e proposta política, o jornal comunista possuía linha editorial que recaía na perspectiva legalista, assim como acontecia ao Sindicato dos Trabalhadores Têxteis ${ }^{5}$. Em suas devidas proporções, lembra bastante a agenda política do Ministro João Goulart quando esteve à frente do Ministério do Trabalho.

Apoiado na unidade nacional entre o Partido Trabalhista Brasileiro (PTB), ao qual fazia parte, e Partido Comunista Brasileiro (PCB), Goulart oficializava o programa de rigorosa fiscalização do cumprimento da legislação trabalhista, e desse modo, as irregularidades deveriam ser levadas ao conhecimento do sindicato, de lá, à Delegacia Regional do Trabalho, e por fim, ao Ministério do Trabalho. Sobre esse aspecto, Jorge Ferreira aponta que à medida que houve integração dos trabalhadores à vida política do país, seguiu-se à cooptação sindical:

A cada ponto nas concessões aos assalariados haveria o nó do controle político sobre eles. Embora esta interpretação, de tão difundida, seja aceita praticamente sem questionamentos, é possível pensar de outra maneira. Mobilizar o movimento sindical, investigar as lideranças autênticas dos operários, aproximar-se das esquerdas e patrocinar a participação dos trabalhadores nos negócios do Estado não se anulavam, ou entravam em contradição com a política de cooptação, de distribuição de empregos e de práticas fisiológicas (FERREIRA, 2005, p. 111).

Todos esses aspectos demandam rigoroso estudo para entendermos como se efetuaram, no Estado do Ceará, as aproximações/confrontos entre trabalhistas e comunistas, trabalhadores e Estado. Percebe-se, porém, do ponto de vista das relações de trabalho e da implantação das leis, uma série de negativas por parte dos patrões da indústria têxtil do Ceará quanto a possibilidade de dialogar, e associado a isso, o despreparo dos órgãos de fiscalização que mal possuíam equipamentos para trabalhar, segundo denúncia do jornal O Democrata (APARELHAGEM..., 1957, n. 3531, sem paginação).

\footnotetext{
${ }^{5}$ No final dos anos de 1940, tomava posse no Sindicato dos Trabalhadores Têxteis de Fortaleza, o interventor indicado pelo Presidente Dutra, Carlos Pessoa. Com a volta das eleições sindicais, o trabalhista Raimundo Lopes Gondim assumiria a entidade entre 1952 e 1962, mantendo-se os comunistas sempre na oposição. Seria apenas em 1963 que uma voz do Partido Comunista assumiria a entidade, na figura de José Ferreira Lima, destituído do cargo no ano seguinte pelo golpe militar.
} 
Sob esse aspecto, O Democrata funcionou como um canal de denúncia pública, de exigência, um mecanismo para forçar o diálogo. Na secção de nome Página Sindical, o jornal publicava uma série de reportagens sobre as condições de trabalho do operariado. Tratava-se de uma coluna cujos objetivos eram arregimentar trabalhadores para a divulgação das ações do movimento sindical, tornando-o um espaço de leitura por parte das entidades que não encontravam acolhida junto aos demais jornais de Fortaleza:

A página "Movimento Sindical", espaço de leitura destinado à classe trabalhadora, tinha condições de mobilizar e arregimentar novos filiados para as entidades ou até mesmo criar novas instituições, tendo em vista que o foco direcionado de leitura atendia a segmento especializado. O alcance do meio impresso, nas demais cidades do interior do Ceará, abria o leque de atuação da página, para atender à população desprovida de informações do meio sindical. A possibilidade de atender também ao núcleo do operariado engajado nas ações da militância, demonstra ainda a articulação do jornal com as tarefas partidárias (LIMA NETO, 2006, p. 162).

O periódico como um todo constava de aspectos relativos à agitação, propaganda e agenda política. Da narrativa militante que se expressava diariamente, de segunda a sábado, numa média de oito páginas, estruturado pela divisão de seis editoriais (Política, Cidade, Polícia, Nacional, Internacional e Esportes), constituía-se uma tipologia de imprensa que além de informar, funcionava também como uma correia de transmissão das lutas. Nessa linha de reflexão metodológica, pode-se citar ainda que:

A imprensa operária, em particular, destaca-se por sua função articuladora de interesses históricos de classe, como fator de agitação e propaganda, na tentativa de aglutinar elementos de uma consciência operária comum (HARDMAN, 2002, p. 311).

Refletindo sobre a cultura das classes subalternas através dos periódicos, Francisco Foot Hardman (2002, p. 307) compreende aqui o entrelaçamento das lutas cultural e política, expressas no ofício do intelectual orgânico, para citar Antônio Gramsci, cujo papel vem tecer a mediação entre a hegemonia burguesa e a consciência da classe operária, ao viabilizar a emergência de uma 
compreensão de mundo distinta, elaborada a partir da generalização, solidariedade e percepção da experiência concreta.

Entre os repórteres, editores, e até mesmo entre os colaboradores do jornal O Democrata ${ }^{6}$, vários intelectuais e trabalhadores de condição de vida um pouco mais abastada aderiram à causa dos explorados. E isto marca a imprensa operária cearense desde o início do século XX (SILVA, 2007, p. 3).

Apesar da certeza de ver interditada a sede d'O Democrata, de forças policias retirá-lo de cena a cada imposição de clandestinidade ao Partido Comunista, ou de o mesmo ser execrado pelas mais diversas correntes políticas (especialmente as de orientação católica), o jornal persistiu, conseguindo manter-se em circulação por mais de 10 anos.

Ao contrário dos demais jornais que circulavam no Estado do Ceará, 0 Democrata incomodava ferozmente as elites, pois era um crítico das injustiças sociais, e como não poderia ser diferente, afetou os planos de Dante Bonorandi. Reafirmando a disciplina e o aproveitamento máximo do tempo e trabalho, o engenheiro vai aprofundando o método de organização da produção têxtil, para o desânimo e crítica do operariado. Observam que a mudança trazida por Bonorandi em nada os beneficiava:

Fomos informados por um grupo de trabalhadores da fábrica de tecidos Santa Cecília que novas medidas arbitrárias acabam de ser postas em prática naquela empresa com a finalidade de roubar e perseguir os operários.

É o caso, por exemplo, do novo sistema de produção em série que implica numa menor produtividade e, consequentemente, numa redução acentuada nos salários dos tarefeiros.

Esclarecem os operários que anteriormente trabalhavam em vários padrões, o que possibilitava um certo equilíbrio na produção, isto porque se não conseguia produzir muito num determinado padrão, essa diferença era compensada por outros tecidos de mais fácil tecelagem.

Hoje, de acordo com a instituição da produção em série, os operários são obrigados a trabalhar num só tecido. Assim, quem pegar mescla, passa a semana toda produzindo em mescla. Essa modificação no sistema de trabalho vem sendo aproveitada pelo gringo Bonorandi para perseguir os operários. Alegando que os

\footnotetext{
6 Entre os editores do jornal O Democrata, durante os anos de 1945 e 1947, pode-se citar: Annibal Bonavides, Odalves Lima, Luiz Batista e Fernando Ferreira. Por vezes os nomes dos editores não eram publicados para resguardar sua própria segurança.
} 
novatos não têm prática, obriga os veteranos trabalhadores a produzirem unicamente em tecidos mais difíceis.

Em virtude dessa nova modalidade de trabalho o salário dos tarefeiros caiu de maneira revoltante: operários que conseguiam recolher 190,00 por semana, trabalhando oito horas por dia, não conseguem hoje, trabalhando 10 horas, mais do que [ilegível].

Os trabalhadores da Fábrica Santa Cecília precisam reagir de maneira organizada contra essa brutal exploração. Mas para isso o que devem fazer inicialmente é comparecer as reuniões do seu sindicato, denunciando as monstruosas perseguições de que são vítimas (REDUÇÃO..., 1952, n. 1644, sem paginação).

A notícia dá a perceber a reorganização do processo de produção afetando a todos, e o novo modo implica em aprofundamento da especialização: evita que o operário perca tempo em se deslocar de uma máquina para outra a fim de trabalhar com matérias-primas diversas, ou mesmo, que mescle o tipo de material a ser trabalhado no maquinário que manuseia. Trata-se de mais uma transformação nos métodos de produção visando, incessantemente, a acumulação de capital.

Para os trabalhadores, essa mudança vai sendo percebida através da subdivisão de cada unidade produtiva em operações sistemáticas (a realização de trabalho com um só tipo de tecido, por exemplo), aumentando a produtividade, fundando a especialização extrema. O tempo livre do operário entre as operações vai sendo transferido para o empresário, no momento em que há também o barateamento da força de trabalho (dividir o trabalho em partes barateia suas partes individuais). É quando se cria o mito do profissional qualificado.

Embora todas as sociedades existentes tenham dividido o trabalho em especialidades, nenhuma delas subdividiu sistematicamente cada especialidade produtiva em operações limitadas como fez o capitalismo - a ideia do trabalhador que domina um determinado ofício é perdida:

Enquanto a divisão social do trabalho subdivide a sociedade, a divisão parcelada do trabalho subdivide o homem, e enquanto a subdivisão da sociedade pode fortalecer o indivíduo e a espécie, a subdivisão do indivíduo, quando efetuada com menosprezo das capacidades e necessidades humanas, é um crime contra a pessoa e contra a humanidade (BRAVERMAN, 1987, p. 72). 
$\mathrm{Na}$ consecução desse processo de alienação do trabalho, a gerência científica (cujo expoente local é Bonorandi) estuda a aplicação de novos métodos para a resolução dos complexos e crescentes problemas do trabalho: controla e fixa cada fase de seu processo, seu modo de execução, estabelecendo e ampliando metas. Ou seja, a gerência pré-planeja e pré-calcula todos os elementos desse processo, já que o operariado não mais participa daquilo que um dia foi do seu ofício; instruindo, portanto, cada um deles sobre como realizar o trabalho na produção dos tecidos.

Para Margareth Rago e Eduardo Moreira (1984), o taylorismo é um novo campo de saber que representará um reforço da dominação nas relações de trabalho, cuja estratégia política dissimulada de método científico, visa constituir trabalhadores dóceis politicamente, e rentáveis economicamente. Através da operação conceitual organização cientifica do trabalho, dá a entender uma racionalidade inscrita na ordem natural das coisas, objetiva, neutra, parcial, e assim sendo, não se pode, e nem se deve, opor resistência.

Nessa tentativa de dissociar a questão técnica da questão política, o temor do capitalista era continuar a ver o operário armado contra o capital, pois recorrendo à tradição, ele teria domínio do ofício e do tempo de trabalho. No projeto taylorista de aprofundamento da divisão, entre trabalho de concepção e de execução, a apropriação do saber operário é imperativa, ao tempo que o capitalista vai se tornando cada vez mais independente do trabalhador, substituível a qualquer momento.

Para o operário, por outro lado, se a prática do esforço rotineiro junto à máquina pode lhe informar táticas de como realizar o trabalho em menos tempo, esse conhecimento quase nunca chega à gerência, ou mesmo ao historiador em busca desses registros, revelando ainda um modo de resistir àquele modelo de produção que somente beneficia o patrão.

Esse movimento científico da sociedade do trabalho advém de um longo processo de aperfeiçoamento, que data da Inglaterra do século XVIII, onde houve uma forte vinculação entre ciência e técnica, ou melhor, um aprisionamento da ciência ao projeto burguês: 
Símbolo do progresso, mas também do medo e da impotência, a máquina foi responsabilizada pela desqualificação do trabalho, pelo embrutecimento do homem, pela instabilidade do mercado de trabalho, pelo rebaixamento da remuneração do trabalho, pela concentração promíscua e perigosa de grandes aglomerados humanos nas cidades. Mas também a ela foi atribuída a potencialização sem limites da força produtiva do homem, a produção em grande escala e consequente barateamento dos produtos manufaturados, a força disciplinadora para a multidão de pobres ainda completamente marginalizados, e enfim, a condição de alavanca mágica do progresso científico...Sobre ela recaíram tantas expectativas e maldições que no início do século XIX ela se tornara na Inglaterra uma questão polêmica de âmbito nacional (BRESCIANI, 1985-1986, p. 16).

No caso em questão, O Democrata caracteriza que está havendo um novo sistema de produção em série, prejudicial aos operários mais antigos, especialmente porque ficaram restritos a trabalhar com um tipo de fio, o mais complexo, obrigando-os a fazerem maior esforço, sob menor índice produtividade, e consequentemente, menores salários; mas o jornal não esclarece que a interiorização do taylorismo também é prejudicial aos mais jovens, que trabalhando com matéria-prima de melhor manuseio, rendendo-lhes maior produtividade, tem por contraponto a saúde danificada pela intensificação do trabalho.

Na dissertação de mestrado de Luciana Ximenes Barros, é captado com maestria o depoimento do operário-militante Guerreiro, que trata exatamente desse momento de interiorização do taylorismo no setor da tecelagem da Fábrica Santa Cecília, onde trabalhava:

Na época houve até paralisação por setor, porque quando eles montaram esses teares, que é uma correria para atender todos aqueles teares. Com três teares a gente já tinha problema, imagina com seis?! Aí o operário resistiu àquilo e eu me lembro que houve paralisação na fábrica. Não tinha condições de atender toda aquela máquina. Mas, com o tempo o patrão dobra, porque despedia e empregava outro, até conseguir dobrar mesmo, e os operários tiveram que se submeter a trabalhar mesmo com seis, oito teares. Agora nesses mais antigos não tinha como. Eram máquinas velhas, superadas mesmo, e a gente não podia atender mais do que três teares (BARROS, 2011, p. 83).

Aqui, o operário está se referindo a substituição, em alguma medida, das máquinas obsoletas pelas automáticas no setor da tecelagem. Percebe-se uma 
memória que retrata o conflito em torno da intensificação do trabalho promovida na época em que Bonorandi esteve à frente do sistema fabril. Lutar, era a palavra de ordem de quem resistia a se tornar homem-máquina.

Voltando ao jornal, a crítica apontada é também quanto ao modo como o italiano Bonorandi faz essa mudança, sobrecarregando, não coincidentemente, o operariado considerado velho para a indústria têxtil. A alegação experiência não convence, especialmente porque isso está localizado num movimento dirigido pelos patrões do Cotonifício Leite Barbosa (fábricas Santa Cecília e Santa Teresa) para forçar a demissão do operariado estabilizado pela lei. ${ }^{7}$

Conversando longe das vistas dos patrões, um grupo de operários se organiza para tomar providências. Primeiro porque as medidas adotadas são arbitrárias, segundo porque somente os penaliza. Eles percebem que no conjunto da novidade, é na diferença da natureza do trabalho a ser realizado que os patrões continuam a se beneficiar, pois os salários foram reduzidos, em especial para um grupo que bem poderia ser considerado o "lumpemproletariado" da indústria têxtil: o tarefeiro! ${ }^{8}$

Nesse momento, a luta sindical seria invocada em todo o Cotonifício Leite Barbosa. Seja na fábrica localizada na capital cearense, seja na fábrica localizada a $154 \mathrm{~km}$ dali, em Aracati. Respeitadas suas especificidades, as demandas chegaram aos seus respectivos Sindicatos dos Trabalhadores, e de lá ganharam os ares da Delegacia Regional do Trabalho, do Ministério do Trabalho, do Tribunal Regional.

Vale destacar, por fim, o impacto da escrita subversiva, que também pode ser confundida com uma escrita de resistência. As letras tiveram força no

\footnotetext{
Percebo uma movimentação semelhante entre esses dois Cotonifícios, em Aracati e em Fortaleza, para forjar a demissão de operários já estabilizados pelo tempo de trabalho (segundo consta na Consolidação das Leis do Trabalho, com 10 anos de trabalho numa mesma empresa, o trabalhador entrava nessa modalidade). Na impossibilidade de demissão, surgem uma série denúncias que me levam a crer num recrudescimento das condições de trabalho para o operariado considerado velho, levando-os a se demitirem em troca de minguada indenização.

${ }^{8}$ Esse grupo de trabalhadores também compõe a categoria operária têxtil, encontrando-se na situação de trabalho mais precarizada, e é em geral composto por mulheres - a remuneração e o tempo de trabalho se concretizam em torno de tarefas executadas, por demanda, vivendo à mercê das encomendas geradas pelo mercado. Na Fábrica Santa Teresa, em Aracati, caso não alcançassem o salário mínimo, em vista do montante variável de encomendas, a lei estabelecia que os patrões deveriam complementar suas rendas até chegarem ao teto mínimo.
} 
enfrentamento das mudanças e das práticas arbitrárias, dando a perceber que os trabalhadores não se enganavam quando reconheciam no jornal uma arma, um modo de publicizar as relações de trabalho na indústria têxtil.

\section{Considerações finais.}

Por meio dessas linhas foi possível ter uma breve visão das relações de trabalho na indústria têxtil cearense, especialmente na Fábrica Santa Cecília. Eram tempos de mudanças, que envolviam desde a forma de produzir tecidos, com a intensificação da disciplina e ritmos de trabalho, até a forma de como patrões e operariado se relacionavam.

Partícipe dessa interação, encontrei o papel das letras, da escrita operária caracterizando, denunciando e propondo ações cotidianas que serviam de contrapressão ao estado de coisas que iam se desenhando na Fábrica Santa Cecília. Nessa escrita subversiva, encontrei também um canal de ação política, modelando-se desde a forma como os subordinados faziam uso dos jogos de linguagem, promovendo uma resistência jamais imaginada pelos dominantes, até mesmo através da ação direta, ou mediada pela via sindical.

Contrapunha-se a ideia de que o lucro auferido deveria ser unilateral e imediato, de que o tratamento deveria continuar a ser desumano, especialmente contra as operárias. Vi também, a luta contra o aprofundamento do modelo de gerência científica de Dante Bonorandi, cujos esforços disciplinadores acabavam por ser hierarquizados pela perspectiva do mando, de práticas rígidas e arbitrárias, de métodos coercitivos.

Na complexidade dessas relações de trabalho, a crítica impera simbolizada na resistência da fala, da escrita, do corpo. Uma percepção do absurdo, referendada em seu contrário, no que seria ideal, idealizado talvez, na condução do trabalho.

Dado o que foi visto até então, a fala operária não reivindica revolução, os limites impostos sobre a produtividade e a alienação do trabalho seriam cenas para outros capítulos da história; e sim dignidade, direitos, aquilo que está na lei e aquilo que a lei não dá conta. Sob esse espectro, na tônica do trabalhismo, 
pensar a industrialização cearense num dos principais pilares da economia (setor têxtil), para esse conjunto do operariado, seria fazê-la ao menos de forma digna, respeitosa, humana.

Devido a restrição do número de páginas, esse artigo procurou apresentar ao leitor uma face bastante recortada da complexa relação entre indústria e mundos do trabalho. Desde já, convido-o a navegar na produção historiográfica da História Social do Trabalho, do Programa de Pós-Graduação da Universidade Federal do Ceará, do qual faço parte.

O convite, seria uma forma de conhecer os mundos do trabalho fora do eixo Centro-Sul do país, emergindo na pluralidade do trabalho livre e em cativeiro, no campo e na cidade, na fábrica e fora dela, daqueles inscritos na Previdência Social e daqueles que nunca tiveram a Carteira de Trabalho assinada, nas relações etárias, étnicas e de gênero, no lazer quase nunca autônomo, mas submetido ao crivo da disciplina industrial, na memória daqueles que teimam em discordar da normalidade da ordem. Trata-se de um forte movimento pela renovação historiográfica, sem perder de vista o universo da experiência classista nas relações sociais. 


\section{Referências}

AMORA, Zenilde Baima. Aspectos históricos da industrialização no Ceará. In: SOUZA, Simone de (coord.). História do Ceará. Fortaleza: Editora Fundação Demócrito Rocha, 1994. p. 121-128.

APARELHAGEM para a DRT. Jornal O Democrata, Fortaleza, ano X, n. 3531, 4 de julho de 1957.

ARAGÃO, Elizabeth Fiúza. A trajetória da indústria têxtil no Ceará: o setor de fiação e tecelagem 1880-1950. Fortaleza: Edições Universidade Federal do Ceará: Stylus Comunicações, 1989. (Projeto história do Ceará: política, indústria e trabalho).

ARAÚJO, Jormana Maria Pereira. Em busca dos direitos: lutas e resistências do operariado têxtil cearense (anos 1940-1960). 2018. Tese (Doutorado em História) - Programa de Pós-Graduação em História Social, Universidade Federal do Ceará, Fortaleza, 2018.

ASSEMBLEIA geral extraordinária dos acionistas do Cotonifício Leite Barbosa S/A, 1951, Fortaleza. Ata para aumento do capital social e reforma dos estatutos. Fortaleza: Cotonifício Leite Barbosa S/A, 1951.

BARROS, Luciana Ximenes. Nas trilhas de um guerreiro: trajetória, visão de mundo e luta de um trabalhador. 2011. Dissertação (Mestrado em História) Programa de Pós-Graduação em História e Culturas, Universidade Estadual do Ceará, Fortaleza, 2011.

BRAVERMAN, Harry. Trabalho e capital monopolista. 3. ed. Tradução: Nathanael C. Caixeiro. Rio de Janeiro: Editora Guanabara, 1987.

BRESCIANI, Maria Stella Martins. Lógica e dissonância: sociedade de trabalho: lei, ciência e resistência operária. Revista Brasileira de História, São Paulo: Anpuh: Marco Zero, v.6, n. 11, p. 7-44, set. 1985/fev.1986.

CÂNDIDO, Tyrone Apollo Pontes. Proletários das secas: arranjos e desarranjos nas fronteiras do trabalho (1877-1919). 2014. Tese (Doutorado em História) Programa de Pós-Graduação em História Social, Universidade Federal do Ceará, Fortaleza, 2014.

CARDOSO, Antônio Alexandre Isídio. Nem sina nem acaso: a tessitura das migrações entre a Província do Ceará e o território amazônico (1847-1877). 2011. 
Dissertação (Mestrado em História) - Programa de Pós-Graduação em História Social, Universidade Federal do Ceará, Fortaleza, 2011.

CERTEAU, Michel. A invenção do cotidiano: artes de fazer. Tradução: Ephraim Ferreira Alves. Petrópolis: Vozes, 1994. v. 1.

D'ARAUJO, Maria Celina. Estado, classe trabalhadora e políticas sociais. In: FERREIRA, Jorge; DELGADO, Lucília de Almeida Neves (orgs.). O Brasil republicano: o tempo do liberalismo excludente: do início da década de 1930 ao apogeu do Estado Novo. Rio de Janeiro: Civilização Brasileira, 2003. p. 214-238. v. 2.

FERREIRA, Jorge. O imaginário trabalhista: getulismo, PTB e cultura política popular (1945-1964). Rio de Janeiro: Civilização Brasileira, 2005.

FONTES, Paulo. Um nordeste em São Paulo: trabalhadores migrantes em São Miguel Paulista (1945-1966). Rio de Janeiro: Editora FGV, 2008.

GONÇALVES, Adelaide. Trabalhador Lê? Revista de Ciências Sociais, Fortaleza, v. 34, n. 1, p. 59-72, 2003.

HARDMAN, Francisco Foot. Nem pátria, nem patrão! memória operária, cultura e literatura no Brasil. 3. ed. São Paulo: Editora UNESP, 2002.

LIMA NETO, Ildefonso Rodrigues. Escrita subversiva: o Democrata, 1946-1947. 2006. Dissertação (Mestrado em História) - Programa de Pós-Graduação em História Social, Universidade Federal do Ceará, Fortaleza, 2006.

LOPES, José Sérgio Leite Lopes. A tecelagem dos conflitos de classe na 'cidade das chaminés'. São Paulo: Editora Marco Zero: Editora Universidade de Brasília: MCT/CNPQ, 1988.

MOURA, Esmeralda Blanco de. Mulheres e menores no trabalho industrial: os fatores sexo e idade na dinâmica do capital. Petrópolis: Vozes, 1982.

NEVES, Frederico de Castro Neves. Multidão e a história: saques e outras ações de massa no Ceará. Rio de Janeiro: Relume Dumará, 2000. 
NOBRE, Geraldo da Silva. Introdução ao jornalismo cearense. Fortaleza: Expressão Gráfica, 2006.

PENA, Maria Valéria Junho. Mulheres e trabalhadoras: presença feminina na constituição do sistema fabril. São Paulo: Paz e Terra, 1981.

RAGO, Margareth; MOREIRA, Eduardo. O que é taylorismo. 1. ed. São Paulo: Brasiliense, 1984.

REDUÇÃO no salário dos trabalhadores da Sta. Cecília. Jornal O Democrata, Fortaleza, ano VII, n. 1644, 5 jul. 1952.

RODRIGUES, Jessita Martins. A Mulher operária: um estudo sobre as tecelãs. São Paulo: Editora HUCITEC, 1979.

SCOTT, James C. A dominação e a arte da resistência: apresentação de Fátima Sá e Melo Ferreira. Tradução: Pedro Serras Pereira. 1. ed. Lisboa: Livraria Letra Livre, 2013.

SILVA, Marcos José Diniz. Modernidade e espiritualismo na imprensa operária cearense da primeira república. Revista Brasileira de História, São Paulo, v. 5, n. 13, [p. 1-10], 2007.

UM VERDADEIRO inferno a vida dos operários da Santa Cecília. Jornal O Democrata, Fortaleza, ano VI, n. 1467, 9 out. 1951.

VERDADEIROS bandidos atuam na Fábrica Santa Cecília. Jornal O Democrata, Fortaleza, ano VI, n. 1957, 9 out. 1951. 